\title{
Mercury intracellular partitioning and chelation in a salt marsh plant, Halimione portulacoides (L.) Aellen: Strategies underlying tolerance in environmental exposure
}

\author{
M. Válega a, ${ }^{a}$, A.I.G. Lima ${ }^{\text {b }}$, E.M.A.P. Figueira ${ }^{\text {b }}$, E. Pereira ${ }^{a}$, M.A. Pardal c ${ }^{\text {, A.C. Duarte }}{ }^{a}$ \\ a CESAM and Department of Chemistry, University of Aveiro, Campus de Santiago, 3810-193 Aveiro, Portugal \\ ${ }^{\mathrm{b}}$ Centre for Cell Biology, Department of Biology, University of Aveiro, Campus de Santiago, 3810-193 Aveiro, Portugal \\ ${ }^{\mathrm{c}}$ IMAR - Institute of Marine Research, Department of Zoology, University of Coimbra, 3004-517 Coimbra, Portugal
}

\section{A R T I C L E I N F O}

\section{Article history:}

Received 19 June 2008

Received in revised form 20 September 2008

Accepted 23 September 2008

Available online 11 November 2008

\section{Keywords:}

Salt marshes

Mercury

Halimione portulacoides

Phytochelatins

\begin{abstract}
A B S T R A C T
In the presence of metal stress, plants can resort to a series of tolerance mechanisms. Therefore field studies should be undertaken in order to evaluate the real role of these mechanisms in stress coping. The aim of this paper was to clarify the biochemical processes behind mercury tolerance in Halimione portulacoides (L.) Aellen (Caryophyllales: Chenopodiaceae) collected in a mercury contaminated salt marsh. Different fractions of mercury were separated: buffer-soluble (mainly cytosolic) and insoluble mercury (mainly associated with membranes and cell walls). The amounts in each fraction of metal were compared and related to metal distribution within plant organs. Protein-mercury complexes were isolated and analysed for their thiol content in order to assess wether the tolerance of this salt marsh plant was associated with the induction of metal chelation by phytochelatins. Overall, the mercury tolerance strategies of the plant are likely to involve root cell wall immobilization as a major mechanism of metal resistance, rather than metal chelation in the cytosolic fraction. Nevertheless, phytochelatins were demonstrated to chelate mercury under environmental exposure.
\end{abstract}

(c) 2008 Elsevier Ltd. All rights reserved.

\section{Introduction}

All over the world, estuaries became attractive areas for human settlements due to their natural features; however such developments have resulted in disturbance and threatening of the integrity of the associated ecosystems, namely salt marshes. Salt marshes have a high and a well defined ecological importance, although for several decades they were regarded as unpleasant areas and became the repositories of industrial and domestic effluents.

Mercury is a highly toxic non-essential element and its dispersion in the environment is considered to be a global concerning problem due to its persistent character. Mercury dispersion results in its accumulation and bioamplification through the trophic chain being the humans subjected to high concentrations of mercury, especially in areas where fish and seafood are the main components of the diet (Wiener et al., 2003).

In aquatic systems, mercury tends to be adsorbed onto suspended particles and removed from the water column into sediments (Covelli et al., 2007). Salt marsh plants can act as traps for suspended particulate matter immobilizing them beneath the bottom sediments and in their roots. Several studies reported that salt marshes located nearby industrialised areas can act as natural sinks for trace metals namely mercury (e.g. Válega et al., 2008a).

\footnotetext{
Corresponding author. Tel.: +351 234370 737; fax: +351 234370084 .

E-mail address: mvalega@ua.pt (M. Válega).
}

The extent of uptake and how metals are distributed within plants can have important effects on the residence time of metals in plants and in wetlands, as well as on their potential release to the adjacent environment. If metals are accumulated into aboveground tissues, they may enter food webs, biomagnifying their effects in each level of the food chain. This information is needed in order to better understand these systems and to assure that the wetlands eventually do not become themselves sources of metal contamination (Válega et al., 2008a).

When a metal concentration is above a certain threshold level, which is variable depending on the metal itself, phytotoxicity induced processes can take place in the plant, such as: changes in the permeability of the membrane cell, reactions with sulphydril groups, affinity for reacting with phosphate groups and active groups of ADP or ATP and replacement of essential ions. According to Clarkson (1972) in Patra et al. (2004), mercury has a high affinity for sulphydril groups and consequently can disturb cellular functions where critical or non-protected proteins are involved, especially those having sulphydril groups in active and regulatory sites important for protein composition or activity. Several studies report that plants can respond to metal stress by several mechanisms, which may include metal immobilization in root cell walls, exclusion or intracellular chelation (Hall, 2002). Some works have demonstrated that metals can be retained by means of extracellular carbohydrates (Wagner, 1993), such as pectic sites or the hystidyl group of the cell wall (Leita et al., 1996), forming very stable 
complexes. Under metal stress conditions, plants usually respond by synthesizing specific peptides or organic acids (Rauser, 1999). A common response is the synthesis of phytochelatins (PCs: (-GluCys $)_{n}$-Gly, where $n$ is generally in the range of 2-5), small metalbinding polypeptides, enzymatically produced from glutathione that sequester metals through thiol coordination, reducing the damage to metabolic processes (Zenk, 1996; Rauser, 1999; Cobbett and Goldsbrough, 2002). When in the presence of toxic metal concentrations, PCs form complexes with the metal ions, preventing them from interfering with the cellular metabolism (Vögelli-Lange and Wagner, 1990; Ortiz et al., 1995; Zenk, 1996).

Although PCs have already been implicated into mercury tolerance (Zenk, 1996), studies of mercury sequestration by PCs are very scarce. Gupta et al. (1998) showed that two aquatic plants (Hyrilla verticillata) and rooted (Vallisneria spiralis) synthesized different species of phytochelatins, during mercury exposure. These studies are relevant to understand the role that phytochelatins play in mercury detoxification. Few reports focus on metal distribution through the subcellular fractions of salt marsh plants and fewer analyse the role of PCs in their metal detoxification, particularly in the field. This is of paramount importance, since most studies on metal tolerance mechanisms rely on laboratory experiments, and such laboratory results are difficult to extrapolate due to several limitations associated to the test conditions which may be from the natural environment, namely the bioavailable fraction of the metal in the sediments. Laboratory tests also tend to be more conservative and usually are performed in a short period of time and with young plants (Powell, 1997). In order to evaluate the real role of these mechanisms in stress coping, field studies should be undertaken and this is particularly true for salt marshes, were a complex equilibrium of different factors may take place.

This work was carried out with samples collected from their natural habitats. The present study was conducted in Ria de Aveiro (Portugal), a southwest European mesotidal system. Ria de Aveiro is a shallow coastal lagoon with several channels and extensive inter-tidal areas. Within Ria de Aveiro there is a confined area called Laranjo Bay which is the one of the most mercury-contaminated coastal areas in Portugal, due to industrial discharges from a chlor-alkali plant between the 1950's and the 1990's. Halimione portulacoides (L.) Aellen (Caryophyllales: Chenopodiaceae) is a perennial salt marsh plant with a wide distribution in the European salt marshes and in the Ria de Aveiro system.

The aim of this paper was to clarify the biochemical processes behind mercury tolerance in $H$. portulacoides. With this purpose, two fractions of mercury were separated: buffer-soluble (mainly cytosolic) and insoluble mercury (mainly associated with membranes and cell walls). The amount of both fractions of metal was compared and related to metal distribution within plant organs. It was also assessed if the tolerance of this species was associated with the induction of metal chelation by phytochelatins. With this purpose, protein-mercury complexes were isolated and analysed for their thiol content.

\subsection{Analytical methodologies}

\subsubsection{Sampling procedure and sample treatment}

Sediments vegetated by $H$. portulacoides were collected in five stations of Laranjo bay (Fig. 1) with different levels of mercury contamination, during low tide in monospecific stands of $H$. portulacoides and then transported to the laboratory under refrigerated conditions. Roots were carefully sorted from the sediments and washed with distilled water to assure that no sediment particles were in the roots. Leaves were also rinsed with distilled water. After the washing process, roots and leaves, were immersed in $5 \mathrm{mM} \mathrm{CaCl}_{2}$, during $10 \mathrm{~min}$, and after washed with distilled water to remove the extracellular metal. Previous washes with distilled water did not provide such good metal removal and using EDTA similar results were obtained (data not shown). Although EDTA is also used for removing extracellular mercury, its presence can interfere with the subsequent complex isolation, because of the high affinity that EDTA has for metals, hence altering the peptide-metal profiles isolated by gel filtration (results not shown). Therefore in this work we used $\mathrm{CaCl}_{2}$ to remove extracellular mercury. The total amount of mercury extracted after the washes with $\mathrm{CaCl}_{2}$ was considered adsorbed mercury. Buffer extracted mercury comprises the soluble fraction and it was assumed to be mainly cytosolic mercury whereas the mercury in the insoluble fraction was assumed as mercury derived from cationic exchange sites in cell walls (Weigel and Jäger, 1980; Khan et al., 1984).

Sediment samples were homogenised, freeze-dried, and sieved $(1 \mathrm{~mm})$ in order to eliminate root debris. Biomass samples were

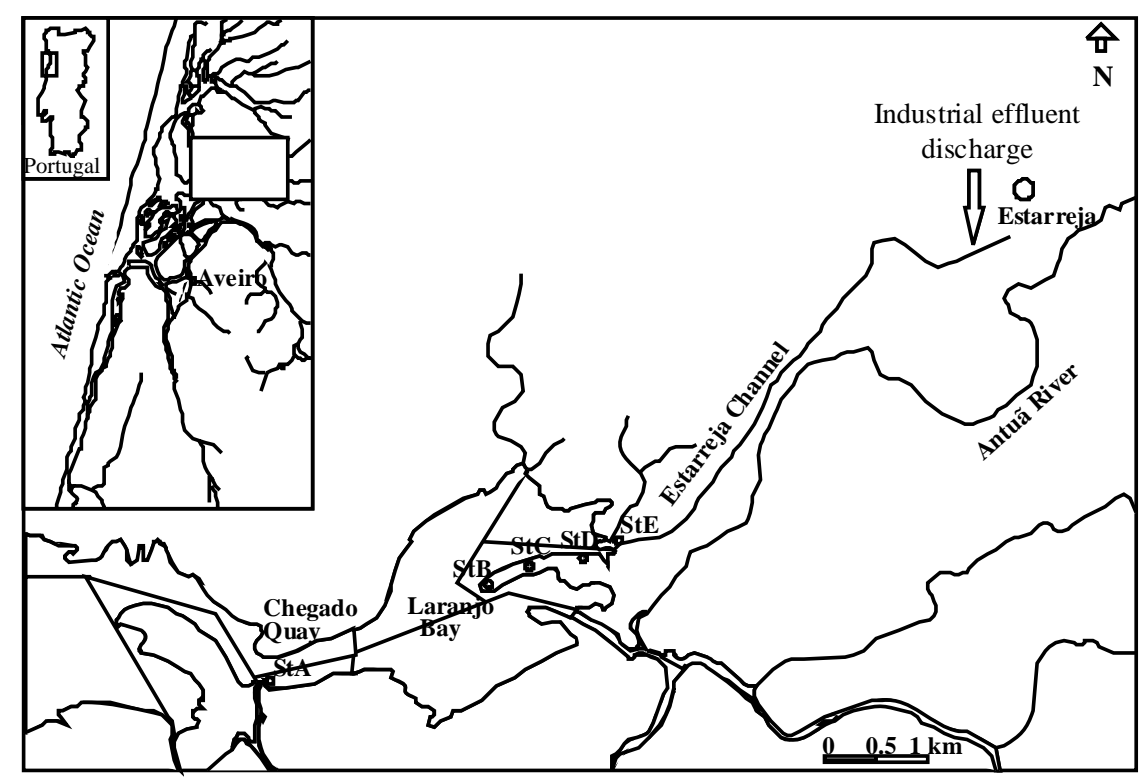

Fig. 1. Map of Laranjo bay with the respective sampling stations. 
homogenised and divided for total mercury analysis and cytosolic extraction. For total mercury analysis biomass samples were oven dried at $45^{\circ} \mathrm{C}$ during several days until constant weight, while the samples for cytosolic extraction of the biomass samples were immediately frozen $\left(-80^{\circ} \mathrm{C}\right)$ and processed in a few days after the collection.

\subsubsection{Extraction procedure}

Frozen root tissues were homogenised essentially as described by Rauser (2000), with $100 \mathrm{mM}$ HEPES (pH 8.6), 1 mM PMSF (phenylmethylsulfonyl fluoride) and $0.2 \%$ Tween $20(\mathrm{v} / \mathrm{v})$, at a ratio of $1 \mathrm{~g}$ of tissue to $1 \mathrm{~mL}$ buffer. The extracted material was centrifuged at $52000 \mathrm{~g}$, during $10 \mathrm{~min}$ at $4{ }^{\circ} \mathrm{C}$ and the supernatant, designed Extract 1, was sub-sampled for metal quantification. The pellet obtained was resuspended in 10 mM HEPES ( $\mathrm{pH}$ 8.6), 0.04\% Tween $20(\mathrm{v} / \mathrm{v})$, with a volume of 1.5 times the fresh weight. The suspension was centrifuged once again and the supernatant was designed Extract 2. This procedure was then repeated four times until 6 extracts were obtained, which together provided the material for the peptide-Hg complex characterization and mercury analysis. Buffer extractions 1-6 were pooled, constituting the soluble (cytosolic) fraction, and freeze-dried. The pellet (insoluble fraction) was also freeze dried.

\subsubsection{Size exclusion chromatography}

Freeze-dried extracts 1-6 were resuspended in $7 \mathrm{~mL}$ of aqueous $0.2 \%$ Tween $20,(\mathrm{v} / \mathrm{v})$ and centrifuged at $48000 \mathrm{~g}$, during $6 \mathrm{~min}$ at $4{ }^{\circ} \mathrm{C}$. The volume of supernatant was measured, subsampled for mercury analysis and fractioned by gel filtration in a Sephacryl S-100 column (326i.d. $\times 112 \mathrm{~mm}$; $119 \mathrm{~mL}$, Amershan Biosciences). The gel bed was equilibrated with degassed elution buffer $10 \mathrm{mM}$ HEPES ( $\mathrm{pH} \mathrm{8.0)} \mathrm{and} 300 \mathrm{mM} \mathrm{KCl}$. Elution was achieved with an injection of $2 \mathrm{~mL}$ of sample and at a flow rate of $0.8 \mathrm{~mL} \mathrm{~min}^{-1}$, at room temperature. The absorbance was registered (Amersham Biosciences detector) at $254 \mathrm{~nm}\left(\mathrm{~A}_{254}\right)$ and fractions were collected (Gilson 201 Fraction Collector) every $3 \mathrm{~min}$ (approximately $2.4 \mathrm{~mL}$ ). All fractions were sub-sampled for mercury quantification and those corresponding to $\mathrm{PC}-\mathrm{Hg}$ complexes were combined and frozen for metal and thiol analysis.

\subsubsection{Determinations of mercury concentrations in sediments and biomass samples}

Mercury concentrations in sediments, roots and leaves were determined by atomic absorption spectrometry (AAS) with thermal decomposition, using an advanced mercury analyser (AMA) LECO 254. This methodology is simple and based on a thermal decomposition of the sample and collection of the mercury vapour on a gold amalgamator Costley et al. (2000). The equipment includes a nickel boat in a quartz combustion tube, containing a catalyst, where the sample (between 50 and $500 \mathrm{mg}$ ) is initially dried at $120^{\circ} \mathrm{C}$ prior the combustion at $680-700^{\circ} \mathrm{C}(150 \mathrm{~s})$ in an oxygen atmosphere. The mercury vapour is collected in a gold amalgamator and after a pre-defined time $(45 \mathrm{~s})$ the amalgamator is heated at $900^{\circ} \mathrm{C}$. The released mercury is transported to a heated cuvette $\left(120^{\circ} \mathrm{C}\right)$ and then analysed by atomic absorption spectrometry (AAS) using a silicon UV diode detector. The major advantage of using the thermal decomposition technique for these determinations is that the sample preparation is quite simplified and no digestion processes is required which implies less manipulation of the samples avoiding crossing contaminations. The accuracy and precision of the analytical methodology for mercury determinations was assed by replicate analysis of certified materials, BCR-060 (trace elements in an aquatic plant) and NRC PACS 2 (trace elements in marine sediment). Certified and measured values were in general agreement, varying the recovery efficiency between $91 \%$ and $102 \%$ for BCR $60 \%$ and $105 \%$ for PACS 2 .
1.1.5. Determinations of mercury concentrations in cytosolic fractions

Extracted solutions were also directly analysed by atomic absorption spectrometry (AAS) with thermal decomposition, using an advanced mercury analyser (AMA) LECO 254. Since extracted solutions are liquid samples the operational conditions used are different regarding the drying time step. For these determinations the operation conditions were: drying time: 350-700 s (depending on the sample volume: $500-1000 \mu \mathrm{L}$ ); decomposition time: $150 \mathrm{~s}$; waiting time: $40 \mathrm{~s}$. The quality control of these determinations were performed using liquid standards, prepared from a $1000 \mathrm{mg} \mathrm{L}^{-1}$ mercury nitrate standard solution (BDH), diluted in similar matrices of the different extraction solutions used.

\subsubsection{Separation and determination of thiol compounds}

For thiol analysis, selected fractions were collected and complexes were dissociated by acidification, as described by Rauser (2000). Monothiols and polythiols in both complexes were separated by HPLC with pre-column derivatisation with monobromobimane ( $\mathrm{mBBr}$ ), as described previously (Lima et al., 2006). Samples $(100 \mu \mathrm{L})$ were neutralised with $0.1 \mathrm{M} \mathrm{NaOH}$, after the addition of $200 \mu \mathrm{L}$ of $0.1 \mathrm{M}$ Tris-HCl buffer (pH 8.0), $1 \mathrm{mM}$ EDTA and $25 \mu \mathrm{L}$ of $2 \mathrm{mM}$ DTE (Ditioeritritol). After incubation for $1 \mathrm{~h}$ at room temperature, $50 \mu \mathrm{L}$ of $20 \mathrm{mM} \mathrm{mBBr}$ (monobromobimane - Calbiochem) were added. Derivatisation was performed in the dark, for $40 \mathrm{~min}$ at a temperature of $35^{\circ} \mathrm{C}$. The reaction was stopped by the addition of $5 \%(\mathrm{v} / \mathrm{v})$ acetic acid, up to a total volume of $1.5 \mathrm{~mL}$. Samples were stored at $4{ }^{\circ} \mathrm{C}$ before HPLC-RP analysis (Klapheck, 1988).

The highly fluorescent bimane derivatives were separated by RP-HPLC (Gilson liquid chromatograph, model 306), as described earlier (Lima et al., 2006). Thiols were resolved and eluted at a flow rate of $1 \mathrm{~mL} \mathrm{~min}^{-1}$ and detected by fluorescence (Jasco 821-FP Intelligent Spectrofluometer) with excitation at $380 \mathrm{~nm}$ and emission at $480 \mathrm{~nm}$ (Klapheck, 1988; Sneller et al., 2000). PC peaks were identified with synthesized PC standards, as described in Lima et al. (2006).

\section{Results}

\subsection{Mercury concentrations in sediments and biomass}

The highest mercury concentrations in the sediments (Fig. 2) were found in StD and StE $\left(15.7 \pm 4.2 \mathrm{mg} \mathrm{kg}^{-1}\right.$ dry weight (dw) and $15.2 \pm 1.7 \mathrm{mg} \mathrm{kg}^{-1} \mathrm{dw}$, respectively \pm stdev), which are the closest to the source of mercury contamination and decreased towards StA $\left(1.9 \pm 0.01 \mathrm{mg} \mathrm{kg}^{-1} \mathrm{dw}\right)$.

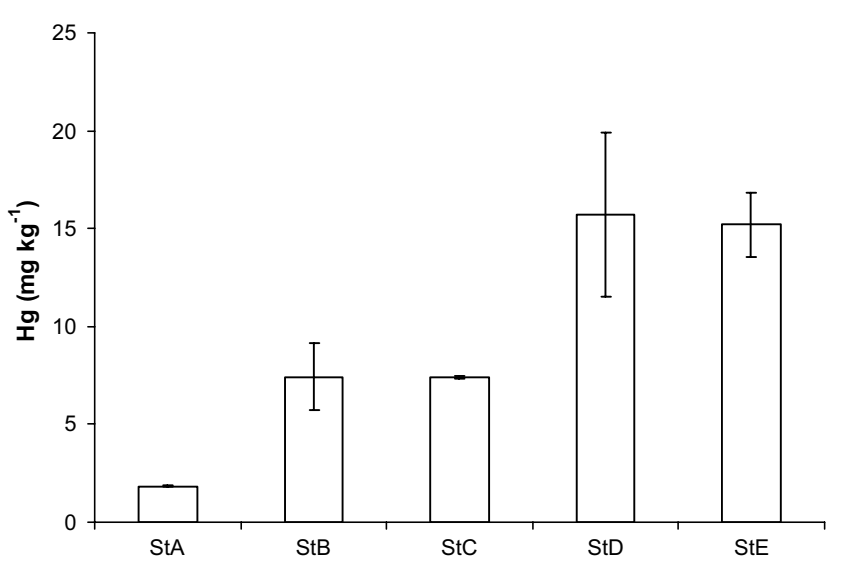

Fig. 2. Mercury concentrations ( $\mathrm{mg} \mathrm{kg}^{-1} \pm$ standard deviation) in the sediments vegetated by Halimione portulacoides collected in the Laranjo bay salt marsh. 
Mercury concentrations in the roots were significantly higher than those found in leaves. Mercury concentrations in the roots ranged between 0.14 and $2.8 \mathrm{mg} \mathrm{kg}^{-1}$ (fresh weight-fw) while in the leaves the values ranged between 0.005 and $0.024 \mathrm{mg} \mathrm{kg}^{-1}$ (fw), being the highest concentrations found in the stations with higher mercury concentrations in the sediments.

According to a recent study (Válega et al., 2008b) $\mathrm{H}$. portulacoides may be used as a biomonitor for mercury contamination in salt marshes ecosystems where leaves responded following a positive linear model for a sediment contamination range between 0.03 and $17.0 \mu \mathrm{gg}^{-1}$, while roots responded according to a sigmoidal model.

\subsection{Plant mercury partitioning}

Fig. 3 shows the partitioning of mercury in roots and leaves of $H$. portulacoides. The Hg present in the six pooled buffer extractions and the remaining pellet allowed to assess the partitioning of metal through the different cellular fractions.

Results show that the most significant amount of the metal was retained in the insoluble fraction. Differences were observed between organs, with leaves presenting higher mercury concentrations in the soluble fraction. The soluble fraction represents only $2-7 \%$ of the total mercury in the roots (Fig. 3a) and $17-28 \%$ in the leaves (Fig. 3b). Despite of buffer-soluble concentrations are very low, statistical correlations were found between the soluble
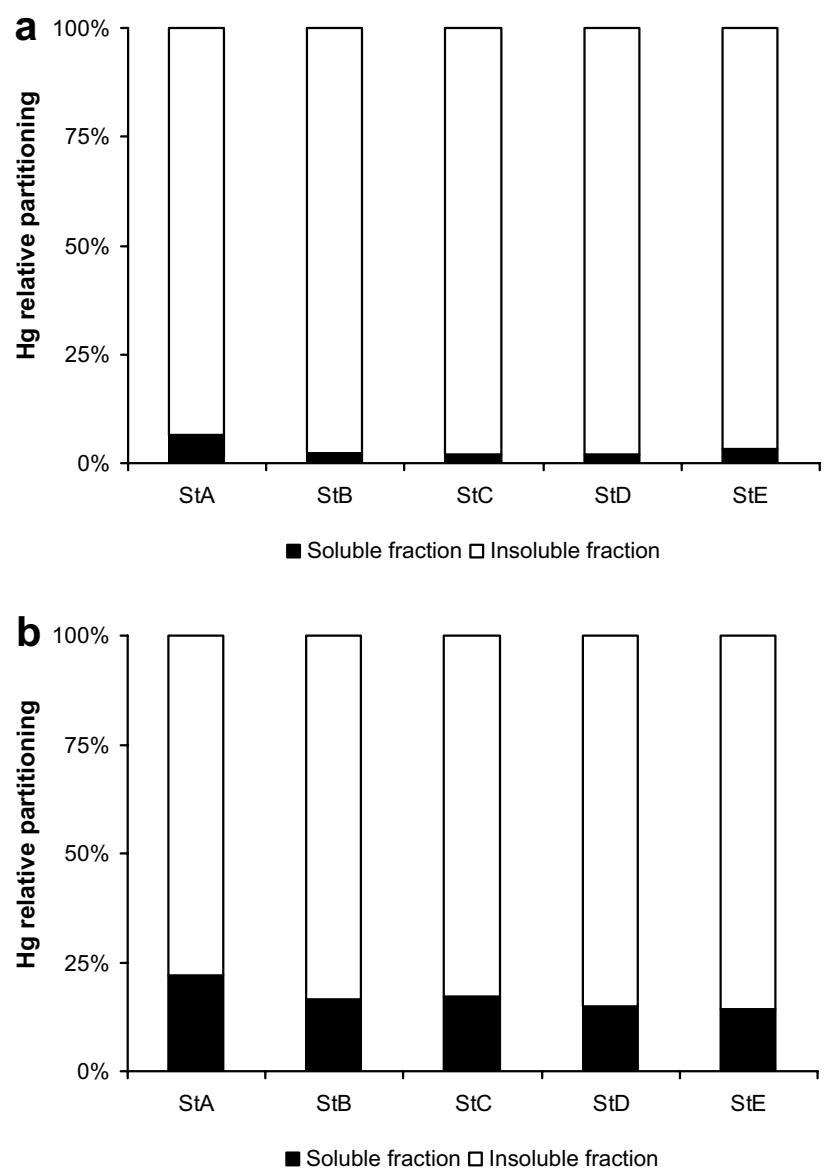

Fig. 3. Plant mercury cellular partitioning between the soluble (cytosol) and insoluble (membranes, cell walls and hydrophilic compounds) fractions in Halimione portulacoides in five stations with different levels of mercury contamination of Laranjo bay salt marsh. The results are the media of three replicates collected in each station. (a) Roots; (b) leaves.
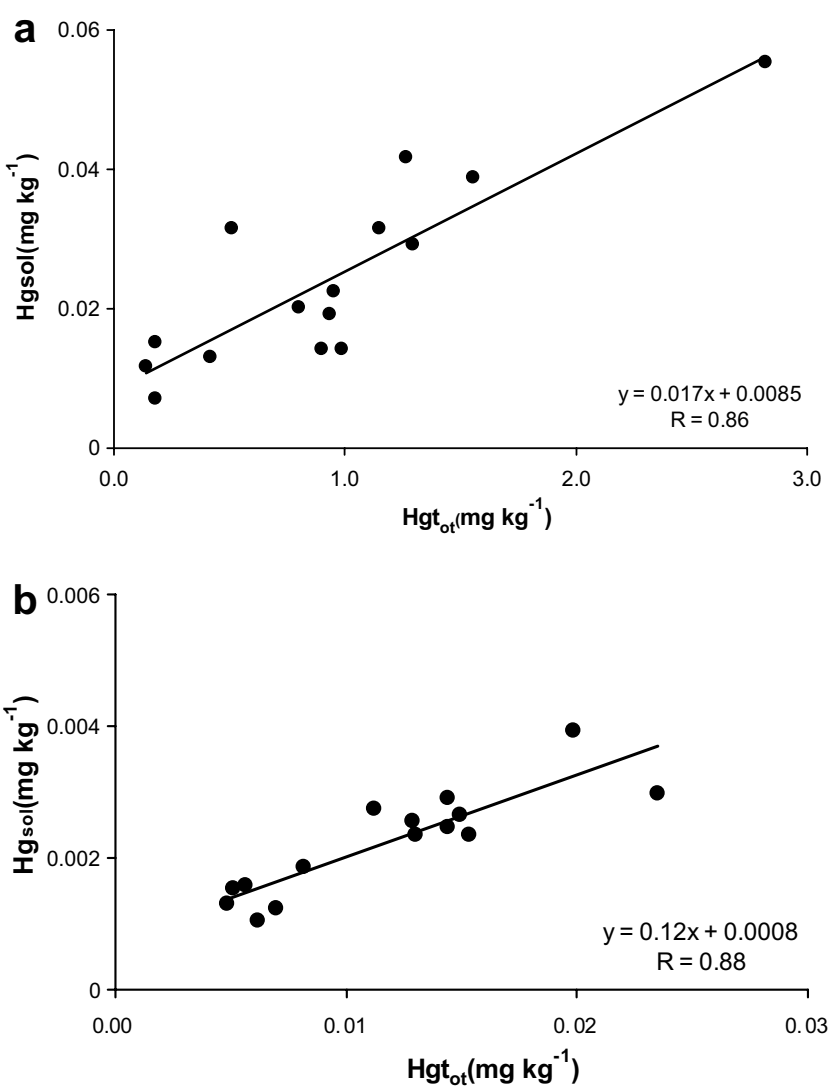

Fig. 4. Correlations between the mercury concentrations $\left(\mathrm{mg} \mathrm{kg}^{-1}\right)$ of the buffersoluble fraction and the total mercury concentrations $\left(\mathrm{mg} \mathrm{kg}^{-1}\right)$ in the organs of Halimione. portulacoides. (a) Roots; (b) leaves.

fraction of the metal and the total concentrations of the roots (Fig. 4a) and the leaves (Fig. 4b).

\subsection{Mercury binding complexes}

Roots were washed with $5 \mathrm{mM} \mathrm{CaCl}_{2}$ in order to remove all extracellular $\mathrm{Hg}$ from the root surfaces as described for other metals (Meuwly and Rauser, 1992; Rauser, 2000).

The freeze-dried material of buffer-soluble mercury was separated by gel filtration. Fig. 5 shows an example of the chromatographic profile obtained for the buffer-soluble mercury from roots of $H$. portulacoides. The mercury distribution among the collected fractions is represented by the histogram. It was observed one major mercury peak, which matched a higher portion of the eluted proteins. Chromatographic profiles show that practically all mer-

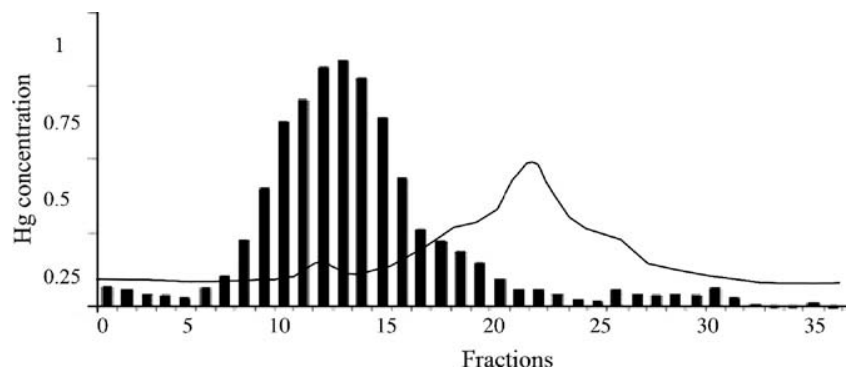

Fig. 5. Example of a size exclusion chromatography of the buffer-soluble mercury. The continuous line corresponds to the absorbance of the eluted proteins ( $254 \mathrm{~nm}$ ) and the histogram corresponds to the mercury concentrations $\left(\mu \mathrm{g} \mathrm{L}^{-1}\right)$ present in each collected fraction. 
cury was concomitant to specific protein peaks instead of eluting as free ions, revealing that all $\mathrm{Hg}$ was present in association with proteins. It was observed $\mathrm{Hg}$ was eluted in a broad peak, matching a wide portion of proteins and that it appeared in the higher molecular weigh fraction of the chromatogram.

\subsection{PCs analysis}

In order to analyse the process of metal chelation in $H$. portulacoides, we set out to analyse whether PCs were present in the mercury complexes isolated by gel filtration. As a basis for comparison, we also analysed the thiol profiles in the other areas of the chromatogram (Fig. 6): area I (fractions 1-6); area II (fractions 7-20) and area III (fractions 21-35), where PCs complexes were
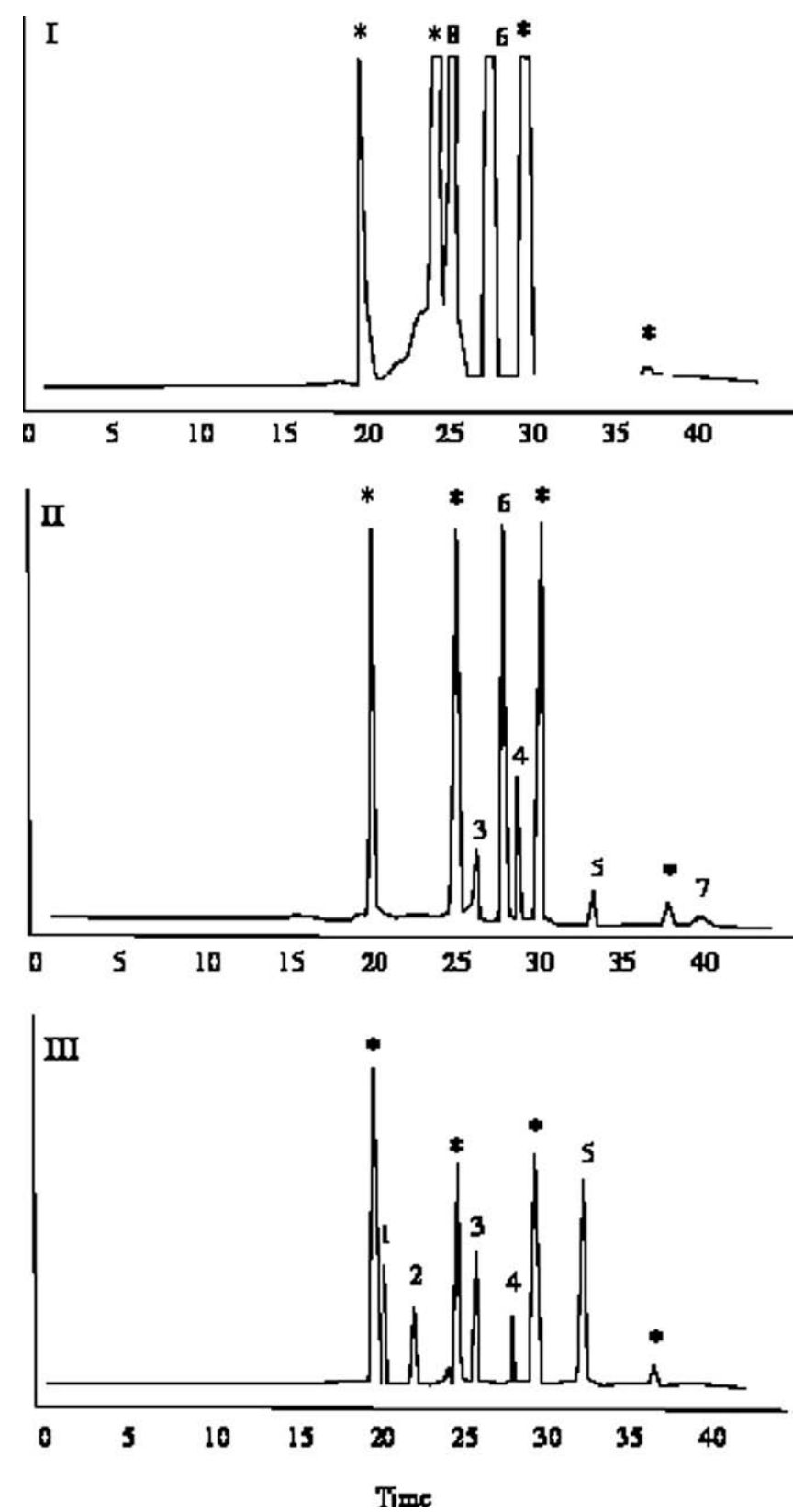

Fig. 6. Example of a chromatographic profile of HPLC analysis of thiol compounds present in the different areas obtained in the separation of the peptide-mercury complexes. Isolated peaks are as follows: (1) $\mathrm{PC}_{2}$; (3) $\mathrm{PC}_{3}$; (4) $\mathrm{PC}_{4}$, (5) $\mathrm{PC}_{5}$, (2), (6) and (7) unknown thiols. Peaks marked with $\left({ }^{*}\right)$ correspond to $\mathrm{mBBr}$ hydrolysis peaks. reported in previous similar studies (Rauser, 2000). Area III comprised polythiols equivalent to phytochelatins (PCs) with 2 to 5 olygomeric repeats $\left(\mathrm{PC}_{2}, \mathrm{PC}_{3}, \mathrm{PC}_{4}\right.$ and $\left.\mathrm{PC}_{5}\right)$, hence demonstrating the presence of PCs, but not associated with mercury. Area I presented low amounts of thiols, comprising some unknown peptides and no PCs. Finally, the mercury containing zone presented the same unknown thiol present in Area I, but also contained few PCs, namely $\mathrm{PC}_{3}, \mathrm{PC}_{4}$ and $\mathrm{PC}_{5}$.

\section{Discussion}

Our results clearly show that roots were the main organs for mercury retention in $H$. portulacoides, which is in agreement with previous studies (Válega et al., 2008a). Metal retention in roots can be a strategy for protecting the more sensitive aerial parts from the deleterious effects induced by metal stress (LozanoRodriguez et al., 1997) and it has been reported that in most plant species, metal ions are preferably retained in the root tissues and only small portions are translocated to leaves.

Besides organ partitioning, the subcellular distribution of heavy metal ions within a certain organ is also a critical factor in tolerance; in fact intracellular free mercury (or metal) ions are reported to be much more toxic than complexed mercury (Cavallini et al., 1999). The knowledge about the metal partitioning through cytosol and cell walls can not only provide information on the degree of toxicity the plant is experiencing, besides allowing to speculate about the metal tolerance mechanisms that plants use to cope with long-term mercury exposures.

According to Nishizono et al. (1989) it is possible for a plant to accumulate large amounts of metal in the root cell walls, without noticeable translocation to the intracellular fractions. Our results show that more than $93 \%$ of the total mercury found in the roots was immobilized in the cell walls and $72 \%$ of the total mercury found in the leaves were in the also in the cell walls. Sousa et al. (2008) found that in the presence of other metals $(\mathrm{Zn}, \mathrm{Pb}, \mathrm{Co}, \mathrm{Cd}, \mathrm{Ni}$ and $\mathrm{Cu})$ similar results were obtained, with metals being mostly retained in the cell wall compartments. According to Zornoza et al. (2002), a higher accumulation of metals in cell walls can function as a protection barrier by reducing the metal concentration in the cytoplasm.

When comparing these results with those observed in metal exposures in controlled laboratory experiments, they differ substantially. In most of these works, the effectiveness of cell wall retention is reduced, possibly because most of them use very young plantlets and very high metal exposures (Sanitá di Toppi and Gabrielli, 1999), which enhance the entry of metal ions into the cell, instead of its accumulation in the cell walls (Lima et al., 2006). The allocation of most of the metal in the cell walls is an efficient and low energy-consuming mechanism, particularly for long-term exposure to metals. Nevertheless, very small mercury amounts could also be found in intracellular fractions. The comparison of the mercury partitioning between the soluble and insoluble fractions allows us to estimate the importance of cell wall retention when facing different toxicity levels. Good correlations were found between the mercury concentrations in the sediments with the soluble mercury in the organs of the plant $(r=0.82 ; n=15 ; p<0.05$ and $r=0.67 ; n=15 ; p<0.05$, for roots and leaves, respectively) along the degree of mercury contamination. Thus the amount of buffer-soluble mercury increases with higher mercury concentrations in the sediments; however when observing the percentages of soluble mercury (Fig. 3), StA which presents the lowest values of mercury contamination in sediments shows the higher values of buffer-soluble mercury as a percentage of the total mercury retained in the respective organs while in the other stations with higher mercury contamination the percentage values are lower, which suggests a defence mechanism of the plant to avoid the presence of cytosolic mercury, which would be much more harmful. 
When facing the presence of toxic metals in the cytosol, plants tend to use chelation mechanisms, which usually involve small peptides and organic acids. Even though PCs have been detected on a variety of plant species, their role in metal detoxification is still unclear. For example, in Lycopersicon esculentum and Arabidopsis plants, PCs seem to be the major mechanism for Cd tolerance (Chen and Goldsbrough, 1994), but in Silene vulgaris their synthesis does not protect plants from exposure to the pressure of metal (De Knecht et al., 1992). Other works (Leopold et al., 1999; Piechalack et al., 2002) suggest that PC formation may only have a partial role in metal resistance and that in higher degrees of stress other mechanisms may be activated. In Pisum sativum, the synthesis of PCs is in fact dependent on the time and degree of exposure (Lima et al., 2006), being reduced with higher and more prolonged exposures. Furthermore, up until now, PCs role in real tolerance, under environmental exposures is a controversial subject.

The plain analysis of $\mathrm{PC}$ production in plants under environmental exposures does not comprove per se that the specific metal in study was chelated by PCs since other metals are usually present in the environment and may interfere with PC synthesis and the complexation process. The best way to study if mercury chelation by PCs is occurring in environmental exposures is through the separation of mercury-peptide complexes. Analysis of the chromatographic profiles reveals that practically all of the scarce intracellular mercury was eluted in the first high-molecular weight protein peak. Previous studies with in vitro exposures of $\mathrm{Cd}, \mathrm{Zn}$ and other metals usually report that metal-phytochelatin complexes are eluted in the final fractions of the chromatogram, in one or more peaks, because of their low molecular weight (Rauser, 2000), and that an occasional peak in the higher molecular weight area is usually due to non-specific adsorption of the metal ions to higher weighted proteins (Meuwly and Rauser, 1992; Rauser, 2000). This peak usually tends to loose its importance throughout the time of exposure. However, in this work, practically all of the buffer-soluble mercury was presented as one individual peak co-eluting with heavier proteins. These results seem to indicate that PCs do not represent the main role in mercury chelation. With this in mind, we set out to analyse the thiol content of the different portions of the chromatogram.

When observing the HPLC separations we can see that different types of PCs were present in the last eluted proteins, clearly demonstrating that $H$. portulacoides did produced PCs. This result can indicate the presence of other metal exposures than mercury in the sample sites, since these PCs were not associated with mercury. Nevertheless, the mercury peak presented some PCs in its constitution, namely with 3, 4 and 5 olygomeric repeats. These results are of significant importance because they show that mercury can be complexed by PCs in environmental prolonged exposures. Due to the high molecular weights of the protein it is plausible that other molecule may be assisting the mercury complexation and that PCs are not the main mercury chelators. A recent work (Marentes and Rauser, 2007) has analysed cadmium speciation in wheat plants and concluded that phytochelatins were not necessarily the major ligands, particularly in leaves. In fact, a cystein-rich protein metallothionein was also shown to be present in the higher molecular weight fractions of gel filtrations of leaf extracts (concomitant to a cadmium peak that differed from the classic phytochelatin-binding complexes). It is therefore possible that higher molecular weighted metallothioneins could also be playing a role in mercury chelation sequestration, in $H$. portulacoides instead of only phytochelatins.

It has also been hypothesised that in the vacuoles, metal ions can also be chelated by other molecules, such as organic acids, sulphide etc, forming heavier clusters, and also possibly releasing some thiols back to the cell (Zenk, 1996; Rauser 2000). For cadmium, it has been demonstrated that a process of bio-mineralization enhances the Cd-binding ability of higher weighted complexes (Mehra et al., 1994; Kneer and Zenk, 1996) and hence increases tolerance.
A replacement of mercury chelators in the vacuoles could also explain the presence of PCs not associated to mercury. This is particularly plausible when roots are more developed and vacuolated, hence presenting higher levels of citrate, malate and oxalate (Sanitá di Toppi and Gabrielli, 1999). But whether the remaining PCs in the chromatogram were released PCs from the mercury complexes or were complexed to other metals remains to be elucidated. However, it seems largely improbable that the higher amount of PCs in the last fraction of the chromatogram would not be associated with any metal cations. It is more likely that in the presence of multi metal exposures, such as the case of environmental contaminations, PCs are synthesised and bind those metal ions that have higher affinity to GSH.

Parallel studies were conducted in Laranjo bay salt marshes which indicate high concentrations of $\mathrm{Pb}, \mathrm{Cd}, \mathrm{Cu}$ and $\mathrm{Zn}$ in the sediments $\left(12.4,0.47,58.8\right.$ and $246.7 \mu \mathrm{gg}^{-1}$, respectively) (Monterroso, 2005). This selectivity would yield a group of different complexes, with different molecular weights and containing different metal ions. A different approach, with concomitant metal exposures would be very interesting in order to understand the role and effectiveness of the PC-based mechanism. This work clearly demonstrates that PC-metal chelation in the environment can be a complex phenomena, possibly with different efficiency rates according to the metal in question.

\section{Conclusions}

The present work provides important evidences of the role of $H$. portulacoides in mercury contaminated salt marshes and of the molecular mechanisms underlying metal stress coping in this species. Results bring out new light on the mercury tolerance strategies of $H$. portulacoides and on the role of PCs in environmental mercury contaminations. Overall, the mercury tolerance strategies of this plant seem to involve root cell wall immobilization as a major mechanism of metal resistance, rather than metal chelation in the cytosolic fraction. Particularly for a perennial species such as $H$. portulacoides, an effective mechanism of metal avoidance would provide ecological advantage, allowing a more efficient establishment and persistence in contaminated areas. Intracellular mercury sequestration by PCs in the environment was also demonstrated in this work. Mercury chelation in environmental exposures seems to be a more complex phenomena than that observed in laboratory experiments, involving the formation of different types of complexes. PCs chelation was demonstrated to occur in mercury exposures in the environment but possibly assisted by other molecules. Analyses of the constituents of the complex (besides mercury and PCs) are currently under research.

\section{Acknowledgement}

This research was supported by the Portuguese Science and Technology Foundation (FCT) through a Ph.D. grant (SFRH/BD/18682/2004) funding M. Válega.

\section{References}

Cavallini, A., Natali, L., Durante, M., Maserti, B., 1999. Mercury uptake, distribution and DNA affinity in durum wheat (Triticutum durum Desf.) plants.. Sci. Total Environ. 243/244, 119-127.

Chen, J., Goldsbrough, P.B., 1994. Increased activity of $\gamma$-glutamylcysteine synthetase in tomato cells selected for cadmium tolerance. Plant Physiol. 106, 233-239.

Cobbett, C.S., Goldsbrough, P., 2002. Phytochelatins and methalothioneins: roles in heavy metal detoxification and homeostasis. Ann. Rev. Plant Biol. 53, 100301135154.

Costley, C., Mossop, K., Dean, J., Garden, L., Marshall, J., Carroll, J., 2000. Determination of mercury in environmental and biological samples using pyrolysis atomic absorption spectrometry with gold amalgamation. Anal. Chim. Acta 405, 179-183. 
Covelli, S., Piani, R., Acquavita, A., Predonzani, S., Faganeli, J., 2007. Transport and dispersion of particulate $\mathrm{Hg}$ associated with a river plume in coastal northern adriatic environments. Mar. Pollut. Bull. 55, 436-450.

De Knecht, J.A., Koevoets, P.L.M., Verkleij, J.A.C., Ernst, W.H.O., 1992. Evidence against a role for phytochelatins in naturally selected increased cadmium tolerance in Silene vulgaris (Moench) Garcke. New Phytol. 122, 681-688.

Gupta, M., Tripathi, R.D., Rai, U.N., Chandra, P., 1998. Role of Glutathione and phytochelatin in Hyrilla verticillata (l.f.) royle and Vallisneria spiralis L. under mercury stress. Chemosphere 37, 785-800.

Hall, J.L., 2002. Cellular mechanisms for heavy metal detoxification and tolerance. J. Exp. Bot. 366, 1-11.

Khan, D.H., Duckett, J.G., Frankland, B., Kirkham, J.B., 1984. An X-ray microanalytical study of the distribution of cadmium in roots of Zea mays L.. J. Plant Physiol. $115,19-28$.

Klapheck, S., 1988. Homoglutathione: isolation, quantification and occurrence in legumes. Plant Physiol. 74, 727-732.

Kneer, R., Zenk, M.H., 1996. The formation of Cd-phytochelatin complexes in plant cell cultures. Phytochemistry 44, 69-74.

Leita, L., De Nobili, M., Cesco, S., Mondini, C., 1996. Analysis of intercellular cadmium forms in roots and leaves of bush bean. J. Plant Nutr. 19, 527-533.

Leopold, I., Gunther, D., Schmit, J., Neumann, D., 1999. Phytochelatins and heavy metal tolerance. Phytochemistry 50, 1323-1328.

Lima, A.I.G.L., Pereira, S.I.A.P., Figueira, E.M.A.P., Caldeira, G.C.N., Caldeira, H.D.S.Q., 2006. Cadmium detoxification in roots of Pisum sativum seedlings: relationship between toxicity levels, thiol pool alterations and growth. Environ. Exp. Bot. 55, 149-162.

Lozano-Rodriguez, E., Hérnandez, L.E., Bonay, P., Carpena-Rui, R.O., 1997. Distribution of cadmium in root tissues of maize and pea plants: physiological disturbances. J. Exp. Bot. 306, 123-128.

Marentes, E., Rauser, W.E., 2007. Different proportions of cadmium occur as Cd-binding phytochelatin complexes in plants. Physiol. Plantarum. 131, 291-301.

Mehra, R.J., Mulchandani, P., Hunter, T.C., 1994. Role of CdS quantum crystallites in cadmium resistance in Candida glabrata. Biochem. Biophys. Res. Co. 200, 1193-1200.

Meuwly, P., Rauser, W.E., 1992. Alteration of thiol pools in roots and shoots of maize seedlings exposed to cadmium: adaptation and developing cost. Plant Physiol. 99, 8-15, Está certo.

Monterroso, P., 2005. Distribuição e comportamento do cádmio, chumbo, cobre e zinco nos sedimentos e coluna de água da Ria de Aveiro. Ph.D. Thesis (in Portuguese).

Nishizono, H., Kubota, K., Suzuki, S., Ishii, F., 1989. Accumulation of heavy metals in cell walls of Polygonum cuspidatum roots from metalliferous habitats. Plant Cell Physiol. 30, 595-598.

Ortiz, D.F., Ruscitti, K.F., McCue, K.F., Ow, D.W., 1995. Transport of metal-binding peptides by HMT1, a fission yeast ABC-type vacuolar membrane protein. J. Biol. Chem. 27, 4721-4728.
Patra, M.M., Bhowmik, N., Bandopadhyay, B., Sharma, A., 2004. Comparison of mercury, lead and arsenic with respect to genotoxic effects on plant systems and the development of genetic tolerance. Environ. Exp. Bot. 52 199-223.

Piechalack, A., Tomaszewska, B., Baralkiewicz, D., Malecka, A., 2002. Accumulation and detoxification of lead ions in legumes. Phytochemistry 60, 153-162.

Powell, R.L., 1997. The use of vascular plants as “field" monitors. In: Wang, W. (Ed.), Plants for Environmental Studies. CRC Press, Lewis publishers, Boca Raton, Florida, pp. 335-365.

Rauser, W.E., 1999. Structure and function of metal chelators produced by plants The case of amino acids, organic acids, phytin and methalothioneins. Cell Biochem. Biophys. 31, 1-31.

Rauser, W.E., 2000. Roots of maize seedlings retain most of their cadmium through two complexes. J. Plant Physiol. 156, 545-551.

Sanitá di Toppi, L., Gabrielli, R., 1999. Response to cadmium in higher plants. Environ. Exp. Bot. 41, 105-130.

Sneller, F.E., van Heerwaarden, L.M., Koevoets, P.L., Vooijs, R., Schat, H., Verkleij, J.A., 2000. Derivatization of phytochelatins from Silene vulgaris, induced upon exposure to arsenate and cadmium: comparison of derivatization with Ellman's reagent and monobromobimane. J. Agric. Food Chem. 48, 40144019 .

Sousa, A.I., Caçador, I., Lillebø, A.I., Pardal, M.A., 2008. Heavy metal accumulation in Halimione portulacoides: Intra -and extra-cellular metal binding sites. Chemosphere 70, 850-857.

Válega, M., Lillebø, A.I., Caçador, I., Pereira, M.E., Duarte, A.C., Pardal, M.A., 2008a. Mercury mobility in a salt marsh colonised by Halimione portulacoides. Chemosphere 72, 1607-1613.

Válega, M., Lillebø, A.I., Pereira, M.E., Caçador, I., Duarte, A.C., Pardal, M.A., 2008b. Mercury in salt marshes ecosystems: Halimione portulacoides as biomonitor. Chemosphere 73, 1224-1229.

Vögelli-Lange, R., Wagner, G.J., 1990. Subcellular localization of cadmium and cadmium- binding peptides in tobacco leaves. Plant Physiol. 92, 10861093.

Wagner, G.J., 1993. Accumulation of cadmium in crop plants and it consequences to human health. Adv. Agron. 51, 173-212.

Weigel, H.J., Jäger, H.J., 1980. Subcellular distribution and chemical form of cadmium in bean plants. Plant Physiol. 65, 480-482.

Wiener, J.G., Krabbenhoft, D.P., Heinza, G.H., Scheuhammer, A.M., 2003. Ecotoxicology of mercury. In: Hoffman, D.J. (Ed.), Handbook of Ecotoxicology. CRC Press, Boca Raton, Florida, pp. 409-463.

Zenk, M.H., 1996. Heavy metal detoxification in higher plants - a review. Gene 179 21-30.

Zornoza, P.S., Vazquez, E., Esteban, M., Fernandez-Pascual, Carpena, R., 2002. Cadmium-stress in nodulated white lupin: Strategies to avoid toxicity. Plant Physiol. Biochem. 40, 1003-1009. 